But other witnesses suggested that no new controls are necessary. As far as the right of a physician to prescribe drugs for unapproved uses is concerned, for example, Dr William Barclay, executive vice-president of the American Medical Association, argued strongly for freedom. And Dr C. Joseph Stetler, president of the Pharmaceutical Manufacturers' Association, said that no new controls are needed to guide drug trials since the present HEW guidelines are adequate if effectively enforced.

Senator Kennedy, for one, seemed convinced, however, of the need for tighter regulation of human experimentation. He took representatives of the AMA to task for failing to provide leadership in ensuring that medical experimentation is carried out ethically, and labelled many of the incidences of abuse revealed during the hearings as "utterly outrageous". Legislation bearing his imprint can be expected.

\section{WEATHER MODIFICATION FAS Wants the Facts}

by our Washington Correspondent

THE Federation of American Scientists has called upon President Nixon to release the facts concerning US weather modification activities over Vietnam during the war, and it has also called for an international treaty banning the use of weather modification as a weapon of war. At a press conference last week, Herbert Scoville, Jun., former deputy director of the CIA, and Gordon J. F. MacDonald, who until late last year was a member of the Council on Environmental Quality, speaking for the FAS, charged that the United States has used weather modification in the Indochina war, at least experimentally.

To back up that assertion, Dr MacDonald cited a passage in the Pentagon Papers which described "Operation Popeye" -an experimental programme which enhanced rainfall over Laos in 1966. The FAS in a press release also cites the fact that on September 8 last year a commercial weather modification firm filed suit against the federal government, claiming $\$ 95$ million because the Pentagon had used a cloudseeding device in violation of the firm's patent rights. Moreover, the federation points out that Melvin Laird, then Secretary of Defense, denied in testimony before Congress last year that weather modification had been conducted over North Vietnam, but pointedly omitted to mention the rest of Indochina.

In calling for an international treaty banning weather modification in warfare, the FAS suggests that such techniques would be "an opening wedge to the use of climate modification, the inducement of earthquakes and other still more terrible weapons. We see geophysical warfare as a Pandora's Box, to which the seemingly inoffensive weather modification may be the disastrous key". Senator Claiborne Pell, together with 18 colleagues, has introduced a resolution into the Senate calling for an international treaty on this topic.

\section{INDUSTRIAL RESEARCH \\ Opfimistic Forecast}

by our Washington Correspondent

THE National Science Foundation has forecast that industrially funded research and development will increase by 22 per cent between 1972 and 1975, rising from $\$ 11,400$ million last year to $\$ 14,000$ million by the middle of the decade. Based on a survey of projections made by the managers of research and development in 55 of the largest US corporations, the NSF forecast also suggests that industrial employment of scientists and engineers will increase by about 10 per cent over the same period.

The optimistic forecast given to the NSF by industrial executives "reflects a generally optimistic view of the economy", the foundation's report notes, and it is tied to expected increases in corporate earnings. During the late 1960 s and early 1970s, corporate earnings declined, and companies tended to cut back in areas which would have little short term effect on profits-administration, marketing and research and development were prime candidates for the axe, the forecast suggests. The knife was not, however, applied with equal force to all items of research and development because applied research was allowed a moderate increase, while basic research was generally held back.

For the next few years, however, the National Science Foundation predicts that industrial funds for basic research will increase from $\$ 520$ million last year to about $\$ 650$ million in 1975 . Of the 47 companies which offered forecasts, only one predicted a decline in spending on basic research, 13 predicted increases of up to 15 per cent, 22 reckoned they would spend between 16 and 35 per cent more, six forecast increases between 36 and 50 per cent, and five said they expected to increase spend-

Table 1 Industrial Expenditures on Basic Research

(Millions of current dollars)

197119721975 (est.)

All industries $\$ 494 \$ 520 \$ 650$

$\begin{array}{llll}\text { Drugs and medicines } & 95 & 105 & 140\end{array}$

Industrial chemicals $100 \quad 105 \quad 125$

$\begin{array}{lrrr}\text { Petroleum } & 22 & 23 & 25\end{array}$

$\begin{array}{lrrr}\text { Electrical equipment } 109 & 115 & 145\end{array}$

$\begin{array}{llll}\text { Aircraft and missiles } 34 & 30 & 40\end{array}$

$\begin{array}{llll}\text { All other } & 134 & 142 & 175\end{array}$ ing on basic research by more than 50 per cent. The breakdown by industry is shown in Table 1 .

The NSF forecast also suggests that many companies have consolidated their research and development operations during the past few years by centralizing the entire research effort, and thereby saving on such costs as library facilities and testing facilities. Moreover, although most of the company officials who responded to the survey said that expenditures required to reduce pollution have not had much effect on basic research spending, "a few of the companies noted that a significant proportion of their basic research programs was devoted to pollution control".

But the report is not entirely optimistic about expenditures on basic research, for it is pointed out that "there appears to be some disagreement regarding the value of basic research. Some companies, although continuing to perform basic research, question whether the results are worth the cost".

\section{Short Notes}

\section{Earthquake Research}

THE plan to transfer earthquake and geomagnetism research and monitoring facilities from the National Oceanic and Atmospheric Administration to the US Geological Survey (see Nature, 241, 362 ; 1973) was still stalled at the end of last week, awaiting final approval from the Office of Management and Budget. The problem is that although the Geological Survey has agreed to pick up the research, which is being dropped by NOAA because of financial stringencies, and although the National Science Foundation has agreed to put up some of the funds, the USGS does not have enough positions allocated in the 1974 budget to staff the facilities involved. Unless OMB agrees to allow the survey to have more personnel, some activities may be dropped completely.

\section{Saturn's Rings}

A RADAR scan of Saturn has produced the surprising suggestion that Saturn's rings may be composed of chlinks of solid rock, and not of dust, gas or ice particles, as widely believed. The scan, carried out by Dr Richard M. Goldstein and Dr George A. Morris, Jun., of the Jet Propulsion Laboratory, produced much stronger signals from the rings than expected. The echoes suggest that the material in the rings has rough, jagged edges, and that the chunks are probably at least a metre across. Fortunately, the Mariner Jupiter-Saturn mission, which is planned for launch in 1977, does not involve passage through the rings. The scan was carried out on NASA's 64 metre antenna at Goldstone in the Mojav Desert. 